This is a self-archived version of an original article. This version may differ from the original in pagination and typographic details.

Author(s): Mihkelsaar, Janar

Title: Dialectic and social heterogeneity in Ernesto Laclau

Year: 2020

Version: Published version

Copyright: (c) Author, 2020

Rights: CC BY 4.0

Rights url: https://creativecommons.org/licenses/by/4.0/

Please cite the original version:

Mihkelsaar, J. (2020). Dialectic and social heterogeneity in Ernesto Laclau. Trames: Journal of the Humanities and Social Sciences, 24(4), 533-548. https://doi.org/10.3176/tr.2020.4.04 


\title{
DIALECTIC AND SOCIAL HETEROGENEITY IN ERNESTO LACLAU
}

\author{
Janar Mihkelsaar \\ University of Jyväskylä
}

\begin{abstract}
The present article aims to examine critically Laclau's claim that the trend toward social heterogenization revokes the Dialectic, or, more specifically, the clear and strict line of demarcation between what falls within the Dialectic and what falls outside of it. Polemicizing with the assumption of this reading, I argue that the appearance of a radical heterogeneity rather exposes the undecidability of relations between the Dialectic and what is a heterogeneity. To undergo the experience of this relation means not only to confront something that dislocates the Dialectic, but also what makes it what it is. The concrete determination of this limit relation is precisely what is at stake in the populist construction of the people, the political articulation of a popular identity. Against this backdrop, I argue that it is not so much Laclau as Agamben who opens the possibility to think about a heterogeneity non-dialectically.
\end{abstract}

Keywords: Agamben, dialectic, heterogeneity, homogeneity, Laclau, populism, relation

DOI: https//doi.org/10.3176/tr.2020.4.04

\section{Introduction}

When reading the works of Friedrich Engels and Karl Marx, one stumbles on an enigmatic figure of the lumpenproletariat, the very lowest segment of the proletariat associated with the set of figures such as vagabonds, nomads, prostitutes, petty criminals, and lazzaroni. From the world-historical perspective of the "class struggle', the lumpen is denounced as an unfit, apathetic and unreliable ally, and because of that it is set outside of what is thinkable and sayable within the rational framework of dialectical materialism. Yet the philosophical and sociopolitical strategy of marginalization, which drives the totalizing logic of the Dialectic, runs aground when the (so-to-speak) 'real' interests and identity of the working class 
(including other classes) are not derivable from the logical contradictions of political economy. Then we have arrived at a point at which heterogeneity bursts forth at every corner and level of modern society, causing the greatest alarm and disgust. This trend toward growing fragmentation and globalization threatens to shatter the dialectical intelligibility of the world.

Marx faces precisely this uncanny threat in his The Eighteenth Brumaire (1852), which recounts a story of the events leading from the revolutionary overthrow of the Orleans monarchy in 1848 to Louis Bonaparte's coup d'état in December 1851. Bonaparte is described as playing cunningly against each other highly diverse social groups and interests, such as the proletariat, the petite bourgeoisie, the republicans, the aristocrats, the big industrialists, and the peasants. In his bid for power, Bonaparte successfully mobilizes diverse social strata. In such a situation, as Peter Stallybrass argues in his essay "Marx and Heterogeneity," Marx is forced "to look at the contingencies of class: class as an unstable yoking together, through political rhetoric, of heterogeneous groups" (Stallybrass 1990: 70; original emphasis). The main lesson to be learned from Bonaparte's usurpation of the state-power is the primacy of contingency and indeterminacy with respect to economy. A political rhetoric, and not an economic logic, shapes the identity and interests of all classes and, ultimately, a social totality in general.

More specifically, Stallybrass sees Marx's exclusion of the lumpen "as a tactical maneuver to establish the dialectic," as a tactical maneuver to restrict the heterogeneity internal to the heterogeneous category of the poor and, in such a way, to organize the collective identity of the proletariat as a revolutionary and collective agent (Stallybrass 1990: 82; original emphasis). However, the exact impact of the lumpen is more controversial than it appears at first glance, since it is not at all clear in what way the explosion of social heterogeneity affects the integrity and coherence - conceptual homogeneity - of the dialectical logic. In Revolution and Repetition (1977), for instance, Jeffrey Mehlman addresses the question of revolution in Marx's political writings and French literature (Hugo, Balzac). In opposition to Stallybrass, Mehlman argues that the Dialectic breaks down when the transparent representation of the proletariat (and other classes) becomes opaque and precarious. Commenting on two opposing points of view, Ernesto Laclau acknowledges the constitutive role of heterogeneity in the moment of homogenization but, nonetheless, sides with Mehlman. For, when the process of social heterogenization can no longer be managed and delimited, there is nothing else to do but to conclude: "heterogeneity undoes dialectical totalization" (Laclau 2005: 263; my emphasis).

However, the present article aims to argue that we do not necessarily have to decide whether the spectacle of social heterogeneity establishes or, inversely, terminates the dialectical intelligibility of the world. Both standpoints, taken separately, fail to hit the mark. To a certain degree, we may concede to the breakdown of the Dialectic, but not to conclude immediately upon it, insofar as a break in the issue does not have to be an absolute annulment. By drawing upon Laclau's style of reasoning, I suggest interpreting the moment of disruption and that of establishment as complementing and re-enforcing one another. Such double reading is imaginable, on the condition 
that the uncontrollable surge of social heterogeneity throws into question an objective relationship between what is a heterogeneous outside and what is homogeneous inside of dialectical mediations, and as a result, exposes the undecidablity of this relation. But, on the other hand, there arises the need of determining the undecidable. This determination is precisely what is at play in Laclau's populist articulation of the 'people.'

All in all, I believe, Laclau fails in thinking of heterogeneity non-dialectically, because it is not simply enough to oppose the static and fixed form of objective relation to the undecidability of relation. In the final section of this article, I argue that the question of a non-dialectical heterogeneity is a point or a 'blind spot' where the post-structural theory of a populist politics subverts itself and goes beyond itself. A testimony of this is Laclau's concise essay "Bare Life or Social Indeterminacy?" that engages with Giorgio Agamben's seminal work, Homo Sacer: Sovereign and Bare Life (1998). What Laclau's critical reading misses, in my view, is that the enigmatic figure of homo sacer paves the path for the conceptualization of a nondialectical heterogeneity.

\section{Relationship between the dialectic and a heterogeneous exteriority}

Throughout his writings, but especially in his On Populist Reason from 2005, Laclau holds a view that the trend towards the growth of social heterogeneity shatters the foundations of the Dialectic. In order to uphold the dialectical vision of a totality, Laclau maintains that it is required to establish and sustain the clear and strict line of demarcation between the homogeneous interiority of the Dialectic and what is heterogeneous to it. In the present section, I argue that this form of relation is an objective relation.

The dialectical train of thought requires demarcations of what falls within the realm of the dialectical transitions (formally, a thesis-antithesis-synthesis structure) from what falls absolutely outside of it. The Dialectic, in spite of itself, rests on "the static assertion of a binary opposition": the objective positivity of a homogeneous inside and that of a pure outside (Laclau 2005: 149). The movement of dialectical transitions toward the final reconciliation or synthesis of all contradictions asserts itself in opposition and over against the otherness of a non-dialectical outside in the figure of a heterogeneity. The figures of a heterogeneous other are marginal residues which (should) bear no relevance whatsoever to the conceptual homogeneity of dialectical mediations, the dialectical intelligibility of actuality. Examples are easy to come by.

Take, for instance, Lectures on the History of Philosophy, where Hegel describes the historical unfolding of the world-spirit from the Orient to its final self-realization in the Occident. In the narration of such universal history, we come across 'grey areas' (e.g. Africa) that have no substantial significance for the self-assertion of reason and freedom. On the wayside of a historical and metaphysical people, there are the 'people without history' (Laclau 2005: 149, 148; see also Hegel: 1986: 129). 
Criticizing Hegel's idealism, Marx delineates the contours of historical periods in accordance with their specific 'mode of production' (i.e. tribal, ancient, feudalism, capitalism) and corresponding 'relations of production' (i.e. the owners of the means of production and the sellers of labor-power). But ultimately, the intelligibility and cohesion of history is established and maintained in relation to the 'parasitic' scum of the working class, that is, from "the absolute 'outsider': the lumpenproletariat" (Laclau 2005: 144; my emphasis). The lumpen is initially taken to have a negligible and peripheral presence vis-à-vis the forward march of world history, defined by the class warfare between the labor and the capital.

According to Laclau, Marx gives to the class struggle a dialectical explanation. "The dialectical explanation [...] presupposes that if there is an antagonistic (that is, contradictory) relation between A and B, I have within the concept of A everything we need to know that it will be negated by B and only by B" (Laclau 2005: 148). Hence, the dialectical contradiction may be deduced purely from the "determinate negation" of A's identity by B. Ideally, B is nothing more than non-A. Purely through a conceptual and rational analysis, we may ascertain that the propositional content of A is logically incompatible with B. This form of contradiction illustrates the relation of the capitalists and the workers (Laclau 2005: 149). Analytically, one can easily demonstrate that the conflict of interests necessarily follows from the predatory working of political economy. The identity of the proletariat exhausts itself in being the negative side, or 'determinant negation,' of the bourgeoisie's aspiration to maximize profits and accumulate capital. And from capitalists' desire to keep wages close to a subsistence level and to appropriate the 'surplus-value,' one may conclude in a logical manner that the workers cannot but resist their exploitation and, consequently, from engaging in the class war to put an end to injustice. These inner contradictions of capitalism are eventually reconciled dialectically into the higher stage of development - a communist society.

In contrast to the esteemed productivity of the industrial workers, the lumpen is viewed as the underclass of a non-productive force, and for that reason it is excluded from the dialectical logic of historicity. Living by the wayside, the lumpen is a form of heterogeneous exteriority, with which there is no real possibility of compromise and cooperation. Given that it is expelled from the sphere of meaning and historicity, it is strictly speaking not representable, which is to say, it is excluded not only from the space of representation, but from the horizon of dialectical representation as such. And yet, the lumpen has a fixed reference and definition (e.g. non-productivity), because of which it is localizable, controllable, and governable (Laclau 2005: 144). This philosophico-political strategy of exclusion, if not annihilation, is necessary for maintaining and guaranteeing the intelligibility and integrity of the Dialectic.

Overall, it is relevant to keep in mind that the binary relation between what is the homogeneous inside of the Dialectic and what is a heterogeneity is, according to Laclau, completely graspable in the absolute knowledge or the "scientific" explanations of dialectical materialism. What sustains the intelligibility and representability of the homogenous interiority of the Dialectic is the possibility to distinguish the positivity of an absolute inside from that of a heterogeneous outside. 
This form of a pure heterogeneity is nothing but the reverse of the Dialectic. This static and fixed form of relationship is in essence an objective relation.

\section{True generality of heterogeneity and social antagonism}

When asked to give a nominal definition of social heterogeneity, Laclau would initially associate it with an absolute exteriority to the order of representation as such (Laclau 2005: 140). But at a time when the complexity, diversity, and plurality of European societies grow to an unprecedented extent, it is more and more challenging, if not altogether impossible, to sustain the full intelligibility of an absolute inside $v i s-\grave{a}$-vis a pure outside. The rigidity of the conceptual determination of the lumpen, as already witnessed by Marx, starts to lose a fixed reference and meaning. In effect, the problematic of heterogeneity starts to show itself "in its true generality" (Laclau 2005: 151). The truth of this generality designates the extension of heterogeneity to the entire terrain of the social.

The trend toward social heterogenization, Laclau suggests, is what began to gather pace from about the 1830s onward. The unstoppable overflow of heterogeneity undermined "the harmonious image of society," where everyone in the social hierarchy of Europe, from the nobility to the peasants, were supposed to have their 'natural' place, corresponding obligations and liberties (Laclau 2005: 142). In Germany, multiple factors contributed to this process, e.g. "rapid population growth, emancipation from serfdom, enclosures, suppression of feudal distinctions in the towns, and so forth" (Laclau 2005: 142). In France, the complications of this trend came into view in the way Bonaparte cunningly lumped together a heterogeneous set of interests in order to seize and ensure power. That manner in which Bonaparte usurped political power and then ruled demonstrated that social identities and their corresponding interests cannot be simply inferred from the objectivity of the economic base. Heterogeneity, previously banished to a periphery, broke out into the center stage.

In consequence, political thinking is forced to begin with the fact of heterogeneity which no 'deep' logic, no grand narrative, is able to cover or explain away. If so, the imminent challenge is to rethink the Marxist delineations of class struggle. In Hegemony and Socialist Strategy, Laclau (with Mouffe) proposes the poststructural theory of social antagonism. At the outset, two dominant conceptions are dismissed (Laclau and Mouffe 1985: 122-127). Firstly, antagonism cannot be a 'real opposition,' in line with which a social division is modeled on the relation of real objects, for instance, of a negative and positive energy, nor are we dealing with a 'logical contradiction,' that is, with an ideal opposition of propositional contents, of ideal non-mundane objects. Following this line of reasoning, one is tempted to drive class struggle from the logical analysis of categories such as the seller and buyer of 'labor' (e.g. Laclau 2005: 83-93); however, neither a real opposition nor a contradiction is adequate for the task, because both are kinds of objective relations, that either between real or ideal realities. 
In that respect, both standpoints are inadequate, for the reason that social antagonism is for Laclau something that is not inherent to the positivity of reality or ideality, but carved out in the heterogeneous field of unfulfilled demands (Laclau 2005: 149). The difficulty of comprehending and identifying an antagonistic frontier is a part of the difficulty of identifying and delimiting the idea of the people. No matter how a popular identity is determined and represented, it always falls short of itself in the sense that it is always less or more than it is imagined to be. People are just too diverse, too plural, too fragmented, too opaque - too heterogeneous. Behind every already established people lurk other peoples who throw into question a unitary political representation and identity. Once social heterogeneity becomes irreducible, it is no longer possible to distinguish clearly and distinctively the proletariat from the lumpen. It hence becomes apparent that an inside cannot be separated clearly and distinctively from an outside. Cohesive identity yields to the heterogeneous plurality of individuals, which threatens to do away with the transparency of a political representation and the people (Laclau 2005: 149-152).

Lalcau sums up the implications of this process thus: "If the heterogeneous excess can be contained within certain limits, reduced to a marginal presence, the dialectical vision of a unified history can be maintained" (Laclau 2005: 143). But if the opposite is the case, meaning, if it is no longer possible to ignore the overwhelming presence of a heterogeneity and fix objectively the inside-outside relation, the intelligibility of the grand Dialectic yields to disintegration, or, alternatively, it can be sustained only through ad hoc modifications like Syndicalism. In order to ascertain whether the Dialectic immediately fades away without any trace left behind, or as another option, whether it survives the premature proclamation of its death, I think it is necessary to probe further into what Laclau names the undecidability of a radical heterogeneity.

\section{Undecidability, or a radical heterogeneity}

In his On Populist Reason, Laclau thinks of social heterogeneity in the sense of 'the real' (Laclau 2005: 108, 152-154; see more: Norval 2004, Thomassen, 2005, Marchart 2005, Biglieri and Perelló 2011). So considered, heterogeneity does not refer to empirical diversity and multiplicity. There is more to it than that. What is at issue here is what is called a 'radical heterogeneity,' which points to the noncoincidence of objectivity and the reciprocal subversions of the heterogeneous and the homogeneous. This kind of mutual implication can also be reformulated as follows: a radical heterogeneity is the condition of possibility and, concurrently, impossibility for the constitution of a communal identity and representation. This section aims to elucidate this idea.

The question is: How the collective identity of the people is represented and shaped in the heterogeneous terrain of the social? To sketch a reply which Laclau gives to this problem, I examine how the proletariat attends and masters heterogeneity that 'inhabits the very heart of a homogenous space' (Laclau 2005: 152; my emphasis). In the early nineteenth century, for instance, the heterogeneous notion of the poor 
lacked 'any stable social ascription,' since, in a social imagination at that point in time, poverty was associated with a wide variety of abject figures, from the nomads to literati, from the rabble to lazzaroni (Laclau 2005: 143; Stallybrass 1990: 83). Against this diverse background of human wretchedness, Marx came to identify the class of classes - the industrial proletariat. By way of reducing and confining heterogeneity in the camp of the poor, the proletariat came to recognize and form itself as a distinctive class with a world-historical mission. The proletariat emerged as a revolutionary subject from the womb of incommensurable multiplicity (Laclau 2005: 143).

More generally, for political representation and identification to be possible, a people have to be capable of drawing its collective identity by means of delimiting and repressing the differential heterogeneity of the social terrain. In the semantic field of many European languages, for instance, the term 'the people' is in itself a heterogeneous concept, signifying both the socio-political whole and the excluded (e.g. 'ordinary people'). And if the identity of a people is to be identified and represented, it must be carved out negatively in relation to what it should not be. Whichever face this negative form of relation takes, it usually refers to a heterogeneous other. Whether it is the plebs, the multitude, the popolo minute, the lumpen, the Pöbel, it is always inherently an integral part of society. The people carries heterogeneity inside itself as something in relation to which it has to establish and secure its own identity. In light of this sociopolitical strategy of a self-institution, heterogeneity is the condition of possibility for the constitution of a popular identity, a social totality in general.

But this very same heterogeneity refers simultaneously to the impossibility of what Laclau names 'communitarian fullness,' a unitary and transparent representation (Laclau 2005: 83-93). This is so, because the bid for mastery of oneself runs up against the limits that are internal to the attempts of homogenization. As long as there are heterogeneous elements that, for one reason or another, cannot be, or resist being, incorporated into the symbolic order of a political representation, the positivity of the people is constantly forced to come to terms with the negativity of an irreducible heterogeneity, that is, with the particularistic character of all identities and demands, on the basis of which it not only shapes itself, but also needs to re-pose itself constantly anew. No matter how the people signifies itself, it is not possible to negate or do away with heterogeneity conclusively. What is repressed is prone to return, and in so doing, disarticulate an already established identity (Laclau 2005: 153).

That is why the people is not a subject that has one indivisible and unified voice (Laclau 2005: 152). The people is instead always re-presented as that what is absent in its substance. The presence of what is absent cannot be explained away with the empirical complexity of social relations or the cognitive incomprehensibility of a social totality. The mismatch between the orders of a representing and a represented is not accidental or caused by ill will or incompetence on the part of leaders; rather, according to Laclau, non-coincidence is a part of the ontological structure of political representation and collective identification as such (e.g. Laclau 2005: 87-88). The presence of heterogeneous elements objectifies the non-identity of the people. 
To undergo the experience of a radical heterogeneity means to run up against the condition of (im)possibility for the popular identity and representation of a people. This line of reasoning makes an outside-inside dynamic much more difficult.

Viewed from within, the relation of the people to heterogeneity is a relation to what appears to be exterior to the space of a political representation. But in the other, opposite view, a heterogeneity presents itself as what inhabits the very intimate interiority of social space. What is carried inside is thus projected to an outside. Or, put paradoxically, a radical heterogeneity is not only something that is exterior to the space of the social, but also that subverts from within the very interiority of a homogenous society. The uncanny experience of a radical heterogeneity exposes "the undecidability between the homogenous and the heterogeneous or, in our example, between the proletariat and the lumpenproletariat" (Laclau 2005: 153). The undecidability of this relation is precisely what is at stake in the self-representation and -identification of a people. Insofar as the interplay of reciprocal subversion of the homogenous and the heterogeneous is constitutive and, in the last instance, undecidable, it puts into question the assumption that an outside-inside relationship is objectively fixed and comprehensible in advance.

That is why, Laclau maintains, the Dialectic enters into a phase of disintegration, for example, because there is no predestined guarantee for the long-term effectiveness of a Marxist militant praxis, leading toward the triumph of communism. What exactly comes into the view in the undecidability of a radical heterogeneity is that there is no intellectual intuition or discursive knowledge on the basis of which to grasp and present the full intelligibility and objectivity of the relation between the homogeneity of dialectical transitions and what is heterogeneous to it. At that moment when the experience of a radical undecidability presents itself as what is irreducible and beyond the reach of control, the dialectic projects of various character collapse. The next section tackles the problem of whether this must necessarily be the case.

\section{At the limits of a dialectical totalization}

If, as discussed above, the undecidability of a radical heterogeneity reveals the conditions of im-possibility for the positivity of the people, it seems the objective intelligibility of an inside-outside relation is irretrievably lost, and, as a result, a dialectical totalization undoes itself irretrievably. The key question is whether we should recap, like Laclau: 'Forget Hegel' (Laclau 2005: 148). To a certain extent, we may concede to this assessment, but in my view such outright reluctance towards the idea of the Dialectic is somewhat perplexing as, throughout his writings, Laclau makes a double gesture: firstly, he registers the moment of a disruption or 'dislocation,' but then takes a step back modestly, evading the equation of the disruption with a nihilist annihilation. The moment of disruption is thereby complemented and interlinked with that of re-establishment.

Many examples illustrate this line of argumentation. Of these, the most wellknown is probably a thesis about 'the impossibility of society,' which does not mean 
that there is no society. At issue here is rather the irreparable loss of an organic society, of immediate communitarian fullness and, correspondingly, the necessity of articulating the identity of a social formation (Laclau 1990: 89-92; see Lipping 2016). Or, as another example, consider the much-touted 'death of the Subject,' which does not imply the outright annihilation of a centered consciousness, of the subject as an absolute foundation for the objectivity of knowledge and reality. Actually, as it comes out, quite the reverse is true: the subject is replaced "with its symmetrical other, that of re-inscribing the multifarious forms of undomesticated subjectivities in an objective totality" (Laclau 1996: 20). The moment of disruption prepares the ground for the proliferation of 'subject positions' and the practice of 'subjectivization.' Another example is how, in the twilight of a transcendent grounding, Laclau nonetheless affirms "a 'ground' which lives only by negating its fundamental character" (Laclau and Mouffe 1995: 193). What is characteristic of the list of such samples is this: the de-substantialization of society and subject and foundation is paradoxically what makes and drives the process of a collective identification, subjectivization, and grounding.

And to be strictly consequential, I think that there is no good reason why the instance of a dialectical totalization has to be necessarily an exception to the abovementioned cases. Even though we may concede the fact that the appearance of a radical undecidability calls into question the clear and strict line of demarcation between an inside and an outside, we do not have to follow Laclau to the end in the conclusion that the dialectical logic entirely collapses under its own weight. Perhaps it is not only more likely but also more feasible that the impossibility of a final synthesis calls into question the objectivity of relation between the full positivity of inside and that of outside, but, in doing so, it does not blatantly undo the relation between what falls within the horizon of the Dialectic and what falls outside of it. Instead of an outright annulment, we may read the appearance of a radical heterogeneity as revealing a point where we are exposed to the limits internal to the process of a dialectical totalization or, more specifically, to the very relation between the Dialectic and what is a heterogeneous outside. Thus, we may determine the experience of a radical heterogeneity as a limit-point where the undecidability of this relation presents itself as such (cf. Žižek 1990, Nancy 2002, Selg and Ventsel 2020).

Just as the non-coincidence of the people acquires a form of presence in absence, so is the Dialectic left to contend with the undecidability of an inside-outside relation (Laclau 1996: 44; cf., Agamben 1998: 29, 59-61, Kitus 2019). At the limits of objectivity, we must come to terms with this matter of fact: the movement of dialectical mediations is established and maintained in relation to what it is unable to incorporate and master. But relationship to heterogeneity is at the same time the exposure of the Dialectic to what it carries within itself and also what it needs to control and project outside, and all that in order to posit and maintain its own integrity and coherence. The relation to a heterogeneity subverts from within the self-relation of the Dialectic. Hence, to undergo the experience of this relation means not only to confront something which dislocates the Dialectic, but also, and perhaps 
more significantly, what makes it be what it is. The constitution of the Dialectic is dependent on the position of relation with something non-relational, i.e., with something that blocks the full actualization of a dialectical synthesis and that is the condition of possibility for a dialectical totalization. This limit form of relation is what Laclau calls a 'non-relational relation.' What is in question at the limits of a dialectical totalization is the concrete delimitation of the relation that links and unlinks both poles of the relata, the Dialectic and a heterogeneous outside. Rather than the relata, the very form of relation is ontologically primary.

The undecidability of a radical heterogeneity disrupts the Dialectic, but this moment of dislocation is only one side of the story: the other is that of establishment. In the next section, I argue that Laclau's take on populism illustrates the spectral survival of the Dialectic, the political determination of a non-relational relation.

\section{Populism: the afterlife of the dialectic}

Hegel's Philosophy of Right recounts the development of the objective spirit that starts from an abstract right and leads to the 'ethical life' (Sittlichkeit). This Dialectic of the spirit culminates in the person of the monarch who embodies the 'concrete universality' of the state. Within the organic unity of the state, "bureaucracy is the universal class, while civil society - the system of needs - is the realm of pure particularity" (Laclau 2005: 107). Later, Marx reverses the idealist point of view: the modern state is understood as an instrument in the hands of particular interests of the bourgeoisie, while a civil society engenders within itself the universal class - the proletariat - the world-historical task of which is to put an end to 'alienation' and to realize human potential to the fullest emancipatory extent (Laclau 2005: 107). In spite of philosophical disagreements with Hegel, Marx's materialism remains captured in the dialectical intelligibility of a concrete universality.

With the uncontrollable surge of heterogeneity, however, the metaphysical discourse of a dialectical universality is exposed to the impossibility of pure universality and pure particularity. Under such circumstances, the proletariat is unable to undergo itself as a concrete universality, a homogeneous and self-identical class. The identity of the workers is ultimately not derivable directly from the objectivity of the economic base. What we get a glimpse of in the absence of a Marxist universality is the breakdown of a dialectical reconciliation in the higher synthesis of the universal and the particular, the whole and the part. But this does not have to mean that the Dialectic simply fades away. Another reading is perhaps more feasible: that the disruption of a dialectical totalization triggers the infinite process of homogenization. This, I would say, is precisely what is at play in a populist politics. But counter to a common standpoint, Laclau refrains from associating the phenomenon of populism with some specific features (e.g. 'uneven development') or referent(s) (e.g. Peronist Argentina). From his perspective, populism outlines the 'essence' of the political, at the center of which lies the political construction or articulation of the people (Laclau 2005: xi). This section aims to illuminate this claim. 
Drawing from Saussure's semiotic idea of signification, the values of signs emerge from being differentially inter-linked into a chain of differences (Laclau 2005: 7177). Similarly, the field of the social can be understood as the field of discourse that is composed of elements, lacking a positive value in itself, which means: all sociopolitical demands are differentially inter-related signifiers. Nonetheless, we are not left with the limitless aggregation of demands and identities, the infinite spectacle of heterogeneity without any limitations. In order to bind together heterogeneous ways of seeing and acting and, by so doing, institute the identity of a people, politics has to find a way to appeal to a wide variety of unfulfilled demands coming from feminists, liberals, conservatives, ecologists. To construct a popular camp, the task is not to find a common interest or to strive toward a diplomatic balance, but to convert the unfulfilled demands of people into "the chain of equivalences" (Laclau 2005: 77-83). This takes place when most differential identities are subverted in relation to an antagonizing other. The social link emerges negatively in opposition to a shared adversary.

Overall, the 'people' is not a pre-given substance, but rather instituted through the political articulation of heterogeneous demands into an equivalential chain. And the relevant thing to keep in mind is that such a populist strategy wants to bring into being something that is directly unsayable. A democratic politics is animated by "the need to name an object which is both impossible and necessary" (Laclau 2005: 72). In order to name this impossible but necessary object (specifically, communitarian fullness), the act of naming needs to subvert a normal signification by way of severing a signifier from its relation to a corresponding signified. When a signifier-signified link is interrupted, we are able to experience a social totality at the zero point of its content. Without standing in for any specific meaning, for instance, the name 'left' manifests itself as being in excess over all signifieds. This is how an empty signifier comes to signify the entire field of the social and to represent the entire chain of equivalences. By way of performing as a 'quilting point' for other demands, the signifier 'left' unifies unfulfilled demands (Laclau 2005: 103). This is how the act of naming endangers performatively the popular identity of a people.

To elucidate this assertion, it is relevant to grasp that the name, which institutes a popular identity, is rhetorical and 'essentially catachrestical' (Laclau 2005: 72). Even when the left expresses a social totality, it is still one struggle among many others, one differential link in the terrain of the social. But this part, which is always incommensurable with its particularity, incarnates in a figurative manner social formation as a whole. Thus, in Laclau, a populist universalization passes through the body of a particularity, and because of the absence of an objective foundation, it cannot be determined in advance what part of the social will succeed in incarnating and representing a popular identity. This comes down to saying that the left is not in a privileged position in comparison to other candidates to perform the homogenizing job. In a situation of crisis, many conflicting political parties lay claim to name the unsayable object, communitarian fullness. Exactly what force occupies a hegemonic position is decided by way of political struggle, the outcome of which is indeterminate, precarious. And what is significant to emphasize, no political force 
is able to transcend fully its own particularity and to become a pure universality. A hegemonic universality, Laclau says, is only an 'ontic' substitute for communitarian fullness.

This is so because the end product of a populist homogenization through the enunciations of an equivalential relation falls short in being all-comprehensive, so long as there are always non-represented, excluded elements on the verges of society. This is to mean that any contending part may challenge and aspire to redefine the idea of what a people is and should be. Whenever this takes place, "[w]e are dealing with a part that attempts to incarnate the whole, with a heterogeneity aspiring to be reabsorbed into a new homogeneity" (Laclau 2014: 217). For that reason, there is no populist homogenization that is able to reconcile tensions within the social between the universal and the particular. What emerges in the political possibility of naming and re-naming the 'people' is the impossibility to obliterate completely the particularity of particularities and absorb fully all social fragments into the pure homogeneity of a collective identity. In consequence, an antagonistic frontier never comes close to being a Manichean clash of the good and the evil: "since the antagonistic frontier involves [...] a heterogeneous other which is dialectically irretrievable, there would always be a materiality of the signifier which resists the conceptual absorption" (Laclau 2005: 152).

In spite of being dialectically irretrievable, the presence of a heterogeneous excess prompts the urgent need to articulate the limit form of relation between an outside and an inside. This delimitation is precisely what is at issue in Laclau's populist conceptions of a democratic politics. Regardless of how the undecidable limits of social objectivity are decided upon, the people will always come across with 'an underdog' who can serve as a new point of departure for the political renaming of the people (Laclau 2005: 150-151). An underdog, whatever its exact historical form, is the figure of a heterogeneous other that no political representation is able to accommodate and master fully, but with which it entertains a limit form of relation. Relation is in essence the position of relation with the non-relational in a double sense. Firstly, a heterogeneity is non-relational in relation to which the people establishes itself as the people. But secondly, it also exposes the impossibility of a social transparency. The populist determination of a non-relational relation reflects the vague, contingent, and performative determination of a non-relational relation between the Dialectic and a heterogeneous outside. In Laclau's populist construction of the people, the Dialectic finds abode where it lingers between pure presence and pure absence, pure life and pure death.

\section{Thinking a non-dialectical heterogeneity}

In building upon the previous analysis, I think we can reject two approaches to the conceptualization of a non-dialectical heterogeneity. The first, the grand Dialectic, pushes a heterogeneous other to the outer periphery of what is intelligible and representable. In doing so, the figure of a heterogeneous other turns out to be nothing 
but the Doppelgänger of the Dialectic. Additionally, the second position does not fare any better. The undecidabiltiy of a radical heterogeneity calls into question the objectivity of an outside-inside relation, yet Laclau does not deem it necessary to challenge the form of relation in general. That is why I think the process of a populist homogenization dislocates and simultaneously re-enforces the movement of dialectical mediations. The presence of an underdog serves as a primary reference point for the dis-articulation and, in other occasions, re-articulation of the people, the disruption and establishment of the Dialectic.

The way in which Laclau celebrates heterogeneity - in contrast to how Marx and Engels denounce it - remains entangled within a dialectical horizon. The idea of a non-dialectical heterogeneity seems to be what drives the populist thinking of the 'people,' but it is also a spot where Laclau's line of thinking stumbles upon its own internal limitations - and exceeds the theoretical borders within which it operates. The experience of a non-dialectical heterogeneity points beyond the populist conception of the political. The best evidence of this is in how Laclau reads Agamben's book Homo Sacer in his concise but illuminative article, "Bare Life or Social Indeterminacy?" (Laclau 2014). In failing to grasp the central idea of Agamben's argumentation, Laclau betrays the radicalness of his own intuition. In what follows, I first succinctly sum up Agamben's central idea and then Laclau's critique; and, finally, I argue that the aporetic figure of homo sacer paves the path towards the exposure of a non-dialectical heterogeneity.

Homo Sacer, the first volume of a multi-volume project, defends a controversial thesis that the juridico-political and philosophical tradition of the Occident hinges on the transition from phone (voice) to logos (language), from zoe to bios - or from the simple natural life to the political life (bios politikos) (Agamben 1998: 7-8). This transition takes place on the threshold where exteriority and interiority, life and law, zoe and bios are indistinguishable. This threshold is the place in which a sovereign decision determines the undecidability of a life-law, outside-inside relation and, in doing so, grounds a juridico-political order. First in the Ancient Greek polis, the moment of a decision inaugurated a political community. In order to assure the normal application of law, an order needs to posit and maintain a relation with 'a naked life.' But this relation is not an objective relation. The law includes life through its very abandonment: "[1]aw is made nothing but what it manages to capture inside itself through the inclusive exclusion of the exceptio: it nourishes itself on this exception and is a dead letter without it" (Agamben 1998: 27). Thus, paradoxically, life is inscribed into a juridico-political order through its very exclusion. Law establishes and maintains relation to life through its abandonment. This abandoned life is the 'bare life' of 'homo sacer (sacred man) who may be killed and yet not sacrificed' (Agamben 1998: 8; original emphasis). The figure of homo sacer is subjected to sovereign violence. The elusive and unsayable enigma of the Occident comes into light with the unraveling of the tradition. What exactly appears is the 'ban' or the limit relation of life and law, outside and inside that has concealed itself in the epochal constellations of metaphysical and juridico-political systems (Agamben 1998: 28-29). 
With this short summary in mind, let us move on to Laclau's analysis. The title - "Bare Life or Social Indeterminacy?" - gives a hint at the main argument of the article. Having read through the text, one faces an either-or choice: essentialism or indeterminacy, necessity or contingency, a full exclusion and a partial exclusion, sovereignty or hegemony, the sovereign ban or the antagonistic relation, a sovereign decision or political articulation. Ultimately, as far as I can tell, this choice comes down to one and the same thing: that homo sacer is presupposed as being a pure outsider who is at the mercy of the sovereign power, to the communal violence of the city (Laclau 2014: 210-213). Viewed from this perspective, Agamben is interpreted as disregarding and downplaying more complicated types of interiority/ exteriority matrices, with the regrettable effect of hypostatizing one extreme figure to the metaphysico-political paradigm of the entire tradition. Very heterogeneous and conflicting cases are violently subsumed under one essentialist, ahistorical or meta-historical concept. In such an analytical framework, there is no room left for subtle historical, sociopolitical distinctions and contextual sensibility. This stands in a sharp contrast to Laclau, who deems the exclusion to be always a reciprocal one: "We do not have lawlessness as against law, but two laws that do not recognize each other" (Laclau 2014: 211). And the heterogeneity of an outsider, understood as an underdog, can be "the starting point for a new collective identification opposed to the law of the city (Laclau 2014: 211; original emphasis). For that reason, there is neither the omnipotent sovereign power nor the absolute powerlessness of homo sacer, neither a pure outside nor a pure inside.

Even though Laclau raises pertinent questions, I think that something significant gets lost in this critical presentation. Rather than accepting his interpretation at face value, we should ask: Is homo sacer actually a pure outsider? Are we really justified to oppose social indeterminacy to homo sacer, political articulation to sovereign decision? The reply to these questions should be negative, in my view, since the primary aim of the homo sacer project is not to uncover a grand scheme which is operative underneath very diverse phenomena. Agamben does not make a step back to the traditional metaphysics, and, correspondingly, to essentialism and foundationalism. The case is actually quite the contrary: Agamben is interested in the crisis of the present in which "the great State structures have entered into a process of dissolution and the emergency has, as Walter Benjamin foresaw, become the rule" (Agamben 1998: 12). The exhaustion of fundamental metaphysical and juridicopolitical concepts brings to light the very threshold or the place of a transition which has concealed itself throughout the historical epochs of the Occident (Agamben 1998: 12). What is at stake on the threshold is neither a pure inside nor pure outside, but rather the limit form of relation itself between life and law, inside and outside, etc. The figure of homo sacer draws attention to the limit relation itself which is obscured in the epochal disclosures of juridico-political and metaphysical orders.

In consequence, Agamben thinks we are confronted with the philosophico-political task of thinking of "the ontological difference no longer as a relation, and Being and being beyond every form of a connection" (Agamben 1998: 61; my emphasis; see more: Mihkelsaar 2015). Or, put otherwise, we have "to think the politico-social 
factum no longer in the form of a relation" (Agamben 1998: 60; my emphasis). The challenge before us today is therefore not to articulate the limit relation between the ontic and the ontological, the exterior and the interior, the heterogeneous and the homogeneous; rather, it is necessary to think the ontico-ontological difference and the social bond as beyond the limit form of relation. Among other things, I maintain that 'beyond the relation' means beyond the Dialectic and, furthermore, beyond the spectral reiteration of the Dialectic, as it takes place in the post-structural conception of populism. What Agamben aims to do in his project is to go beyond both the pure heterogeneity of the grand Dialectic and beyond the heterogeneity of an underdog. Heterogeneity, when considered strictly non-dialectically, does not put in motion the populist articulation of the mobile frontier between the proletariat and the lumpen, which is to say, Laclau's naming of the 'people.'

When faced with the appearance of homo sacer, we witness the exhaustion of both sovereign decision and political articulation, the consummation of both class struggle and the mobile antagonistic frontier of 'society.' To strive toward thinking of the politico-social factum beyond the form of relation means to render not only the apparatus of sovereignty but also the populist naming of the people 'inoperative' (Agamben 1998: 61-62). In this manner, Agamben calls into question the very form of relation between the Dialectic and what is heterogeneous to it. The idea of inoperativity strives to pave the path toward a heterogeneity that is not trapped within the schemas of dialectical totalization and its spectral remnants.

\section{Acknowledgements}

This research was supported by the KONE Foundation.

Address:

Janar Mihkelsaar

University of Jyväskylä

Department of Social sciences and Philosophy, Unit of Political Science

Keskussairaalantie 2, PO Box 35

E-mail: janar.mihkelsaar@gmail.com

Tel.: +372 55559292

\section{References}

Giorgio A. (1998) Homo sacer: sovereign power and bare life. Stanford, CA: Stanford University Press. Biglieri P. and G. Perelló (2011) “The names of the real in Laclau's theory: antagonism, dislocation and heterogeneity". Filozofski vestnik 32, 2, 47-64.

Hegel, G. W. F. (1986) Vorlesung über die Philosophie der Geschichte. Frankfurt am Main: Suhrkamp. Kitus, A. (2019) “The theory of hegemony: Laclau's path not taken”. Philosophy \& Social Criticism November, 1-19. doi: https://doi.org/10.1177/0191453719889987 
Laclau, E. and C. Mouffe (1985) Hegemony and socialist strategy: towards a radical democratic politics. London: Verso.

Laclau, E. (1990) New reflections on the revolution of our time. London: Verso.

Laclau, E. (1996) Emancipation(s). London: Verso.

Laclau, E. and L. Zac (1994) "Minding the gap: the subject of politics". In: E. Laclau, ed. The making of political identities, 11-39. London: Verso.

Laclau, E. (2005) On populist reason. London: Verso.

Laclau, E. (2014) The rhetorical foundations of society. London: Verso.

Lipping, J. (2016) "The hedgehog from the pampas: Ernesto Laclau and the impossibility of society". European Political Science 15, 271-276.

Marchart, O. (2005) "In the name of the people: populist reason and the subject of the political". Diacritics 35, 3, 3-19.

Mehlman, J. (1977) Revolution and repetition: Marx/Hugo/Balzac. Berkeley: University of California Press.

Mihkelsaar, J. (2015) “Towards a rethinking of Laclau and Mouffe's conception of social antagonisms: Agamben's critique of relation”. Philosophy Today 59, 3, 409-427.

Nancy, J.-L. (2002) Hegel: the restlessness of the negative. Minneapolis: University of Minnesota Press.

Norval, A. (2004) "Hegemony after deconstruction: the consequences of undecidability". Journal of Political Ideologies 9, 2, 139-157.

Selg, P. and A. Ventsel (2020) Introducing relational political analysis: political semiotics as a theory and method. London: Palgrave.

Stallybrass, P. (1990) "Marx and heterogeneity: thinking the lumpenproletariat". Representations 31, 69-95.

Thomassen, L. (2005) “Antagonism, hegemony and ideology after heterogeneity”. Journal of Political Ideologies 10, 3, 289-309.

Žižek, S. (1990) "Beyond discourse-analysis". In E. Laclau New reflections on the revolution of our time, 249-260. London: Verso. 